\title{
Grazing and sedimentation of ice algae during and immediately after a bloom at the ice-water interface*
}

\author{
Christine Tremblay ${ }^{1}$, Jeffrey A. Runge ${ }^{2}$, Louis Legendre ${ }^{1}$ \\ ${ }^{1}$ Département de biologie, Université Laval, Québec, Canada G1K 7P4 \\ ${ }^{2}$ Institut Maurice-Lamontagne, Ministère des Pêches et Océans, C.P. 1000, Mont-Joli, Québec, Canada G5H $3 Z 4$
}

\begin{abstract}
Sinking of pigmented particulate matter during and immediately after an ice algal bloom was studied in southeastern Hudson Bay at a $45 \mathrm{~m}$ deep station, using consecutive short-term deployments of sediment traps $30 \mathrm{~m}$ below the undersurface of the ice. Cell sinking and grazing by herbivores were assessed by measuring the vertical fluxes of chlorophyll a and phaeopigments. There were 2 peaks of cell sedimentation, a minor one during the first half of the bloom (mid-April) and a major one at the end of the bloom (mid-May); both were related to atmospheric warming events. The fluxes of both phaeopigments and fecal pellets (mainly from large herbivores) increased at the end of the bloom as ice algae were released from the ice environment. The total export of ice algae to the benthos (sinking cells + fecal pellets) was estimated to be ca $20 \%$ of the ice algal production during the measurement period. A large proportion of ice algal production (ca 30\%) was still suspended in the upper water column at the end of the sampling season. The fate of the remaining $50 \%$ is not known, but it is hypothesized that a significant fraction was retained in the pelagic environment.
\end{abstract}

\section{INTRODUCTION}

In polar and subpolar regions, seasonal sea ice supports a community of microalgae which is dominated by diatoms (review by Horner 1985). In the Arctic, the contribution of ice algae to yearly production is thought to be around $3 \%$ (Subba Rao \& Platt 1984, Demers et al. 1986), although it seems to vary widely from region to region depending on the length of the season of pelagic productivity (Alexander et al. 1974, Booth 1984). The ecological impact of ice algal production is potentially important (Alexander 1980, Booth 1984) since the bloom of ice algae occurs earlier than the spring phytoplankton bloom (Apollonio 1965, Legendre et al. 1981, Horner \& Schrader 1982) and is, for a while, the only primary input in the ecosystem. Ice-associated production is an important source of food for sympagic organisms (Carey 1985) and could extend the grazing season

\footnotetext{
- Contribution to the programs of GIROQ (Groupe interuniversitaire de recherches océanographiques du Québec) and of the Maurice Imamontagne Institute (Department of Fisheries and Oceans)
}

of pelagic copepods (Bradstreet \& Cross 1982, Runge \& Ingram 1988).

Three possible fates of ice microalgae in the spring are: (1) suspension in the water column, (2) sinking to the bottom as ungrazed cells, or (3) ingestion by herbivores in the ice, at the ice-water interface, or in the water column (Horner 1984). The relative importance of these 3 pathways is still unclear, especially the relative contributions of ice algae to the benthic and pelagic environments. It has been suggested that ice algal production is only weakly connected to the pelagic system and that most of it sinks out to the benthos (Apollonio 1965, Alexander 1980). However, other investigators have hypothesized that most of this production goes to grazers in the upper part of the water column (Green 1976, Cross 1982). The level of incorporation of ice algal production into the pelagic system might depend on water depth (Alexander 1980), on the structure of the grazing community (Niebauer et al. 1981), or on the rate at which ice algae are released in the water column (Horner 1984, Roff \& Legendre 1986). Sediment trap studies conducted in ice-covered areas suggest that the relative importance of grazing and cell sinking varies regionally (Fukuchi \& 
Sasaki 1981, Dunbar et al. 1985a, b, Atkinson \& Wacasey 1987, Carey 1987, Hsiao 1987, d'Anglejan \& Biksham 1988) and perhaps seasonally (Sasaki \& Hoshiai 1986). In addition to difficulties related to the quantification of grazing and sinking losses, problems in interpreting the results of these studies arise because traps have often been deployed for a limited portion of the bloom period, or algal biomass in bottom ice or at the ice-water interface was not measured during trap deployments.

In the present study, we investigated the relative importance of herbivory and sedimentation as loss mechanisms of algae during the ice algal bloom in southeastern Hudson Bay. Our approach was to use short, consecutive deployments of sediment traps from the beginning of the bloom until $10 \mathrm{~d}$ after algae were released from the ice-water interface. As Welshmeyer \& Lorenzen (1985), we assessed cell sinking and grazing by large herbivores by measuring the vertical fluxes of chlorophyll a and phaeopigments. Algal biomass at the interface and in the water column was monitored in parallel with flux measurements. Fecal pellets in traps were also examined in order to identify potential grazers.

Conversions of fluxes of phaeopigments into grazing rates are based on 2 assumptions (Welshmeyer \& Lorenzen 1985): (1) that grazing is the main process leading to the degradation of chlorophyll into phaeopigments, and (2) that chlorophyll is degraded in a predictable way duning digestion. While pigment losses around $35 \%$ are the most common result of feeding experiments with copepods (Shuman \& Lorenzen 1975, Helling \& Baars 1985, Kiørboe \& Tiselius 1987), other studies show that losses may be very high, over $90 \%$ for Calanus hyperboreus (Conover et al. 1986, Wang \& Conover 1986) or as low as $11 \%$ for Neocalanus plumchus (Dagg \& Walser 1987). Such variability between species and perhaps between seasons, if real, would greatly undermine any pigmentbased approach. For this reason, we also conducted chlorophyll degradation experiments using herbivores from Hudson Bay.

\section{MATERIAL AND METHODS}

Sampling and field experiments were conducted in southeastern Hudson Bay $\left(55^{\circ} 30.1^{\prime} \mathrm{N}, 77^{\circ} 44.9^{\prime} \mathrm{W}\right)$, at a land-fast ice station located $22 \mathrm{~km}$ north of Kuujjuarapik (Fig. 1), from 13 April to 26 May 1986. The site is a subarctic, midshelf environment with high ice algal standing stocks (Gosselin et al. 1986, Roff \& Legendre 1986). The station was located above a submerged cape (water depth: 40 to $45 \mathrm{~m}$ ) gently sloping seaward with landward depths in excess of $100 \mathrm{~m}$.

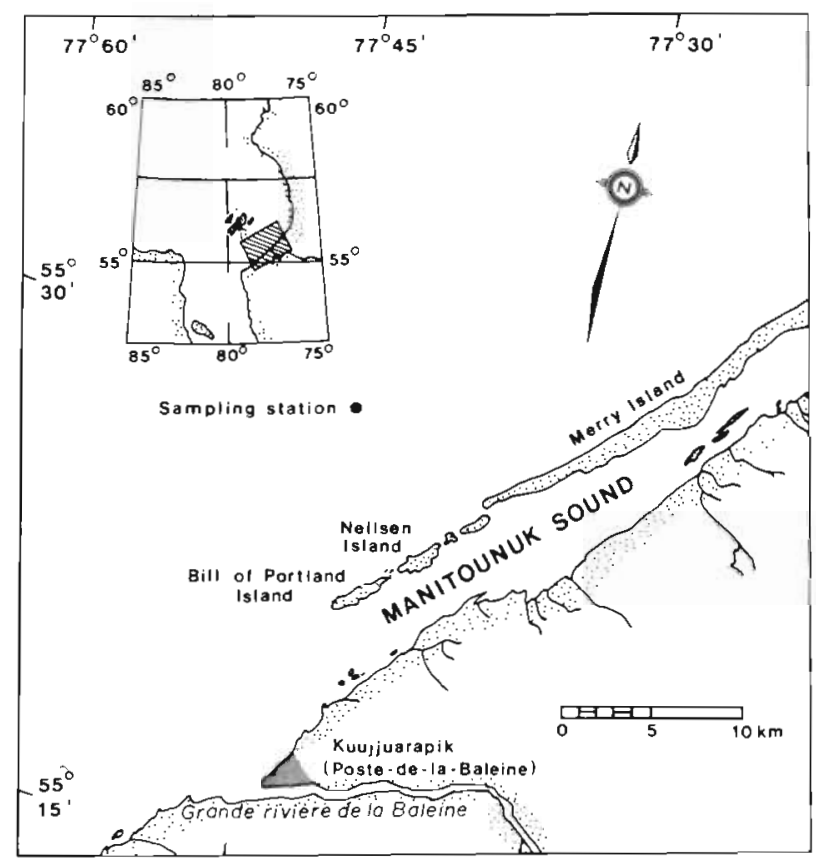

Fig. 1. Location of sampling station in southeastern Hudson Bay

The sampling of algae at the ice-water interface was designed to take into account strong horizontal patchiness (Gosselin et al. 1986). Every 4 d, SCUBA divers made a visual estimation of the proportions of underice area covered by each of 3 visually-determined zones of algal density (high, medium, low). Samples of known width and length were collected from each zone with a suction gun device (2.2 l syringe with mouth diameter of $5 \mathrm{~cm}$ ) which effectively removed all interfacial algae in its path. These samples were analysed for

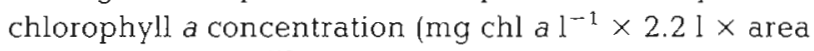
sampled $\left.{ }^{-1}\right)_{i}$ an overall mean areal concentration was then calculated by averaging the chlorophyll concentration in each zone weighted for percent coverage. Between 2 sampling dates, divers sometimes determined percent coverage without collecting samples, in which case we used linear interpolation to estimate chlorophyll concentrations in high, medium and low density patches. Water column concentrations of chlorophyll a were determined from samples collected at $2.5,7.5,15$ and $30 \mathrm{~m}$ depths with Niskin bottles (distances measured from bottom of the ice). Periodically, water samples from the interface and from the water column $(2.5 \mathrm{~m})$ were preserved with acid Lugol's for cell enumeration

Sediment traps were transparent, plexiglass cylinders $41 \mathrm{~cm}$ high and $10 \mathrm{~cm}$ diam. These were closed with a messenger release system, and brought back to the surface with a hand-operated winch. Three traps mounted on a rosette and 2 single traps were set in a 
$50 \mathrm{~m}$ triangle, at a depth of $30 \mathrm{~m}$ (10 to $15 \mathrm{~m}$ from the bottom). They were moored to the ice, and kept vertical by weights attached to the free end of the wires. Because preservatives can affect pigment integrity (Smetacek et al. 1978), no poison was used in the traps. Sedimented material was collected from the 5 traps every 2 to $3 \mathrm{~d}$. The contents were visually examined, then carefully stirred and poured into $4 \mathrm{l}$ dark plastic bottles. Traps were redeployed within 30 min of sample collection. Less than 1 h later, two $250 \mathrm{ml}$ subsamples were filtered from each sample for pigment determination. A $100 \mathrm{ml}$ subsample from a trap on the rosette was also preserved with $1 \%$ acid Lugol's (Hargrave et al. 1976) for size measurements of fecal pellets. Fecal pellets were counted on Whatman GF/F filters onto which $250 \mathrm{ml}$ had been filtered. Fecal pellets, in particular small ones, appeared to be better preserved on filters. When broken pellets were found, these were sorted by width categories $(<60 \mu \mathrm{m} ; 60$ to $100 \mu \mathrm{m}$; $>100 \mu \mathrm{m}$ ), measured, and their length divided by the mean length of fecal pellets in the given category. Pellet numbers were converted to volumes by computing mean dimensions for each type of pellets using equations for a cylinder or an ellipsoid.

Two feeding experiments were conducted, on 8-9 May and 18-19 May, using 5 groups of large copepods and 2 groups of medium-sized copepods. Zooplankton was captured at the ice station with a $1.25 \mathrm{~m}$ diam., $333 \mu \mathrm{m}$ mesh net, towed from bottom to surface. Medium-sized copepods (Pseudocalanus spp. and a few Calanus glacialis CIII) were isolated by gentle sieving through $1000 \mu \mathrm{m}$ and $333 \mu \mathrm{m}$ Nitex screens. Large copepods (C. glacialis females and CIV) were handpicked with a pipette. All copepods were allowed to empty their guts for 8 to $10 \mathrm{~h}$ at 0 to $1{ }^{\circ} \mathrm{C}$ in plastic jars containing filtered seawater. At the start of the experiment, water in the plastic jars was replaced with $1.5 \mathrm{l}$ of a diluted culture of Thalassiosira weissflogii of known concentration. Copepods were maintained at 0 to $1{ }^{\circ} \mathrm{C}$ for periods varying between 10 and $30 \mathrm{~h}$. At the end of the feeding period, copepods were preserved in $4 \%$ formalin. Fecal pellets were collected with a $64 \mathrm{\mu m}$ Nitex screen, resuspended in filtered seawater and subsampled for analysis of fecal pigments. The filtrate was used to determine the final concentration of food. Total amounts of pigment remaining in the guts of herbivores were estimated assuming that each female C. glacialis contained 100 ng pigment and each Pseudocalanus spp., 1 ng pigment. We assumed that $C$. glacialis copepodites were not feeding (own obs.).

Algal and detrital particulate matter collected on Whatman GF/F glass fiber filters was immediately deep-frozen in liquid nitrogen; frozen samples were analyzed within 2 wk after sampling. After 24 h extrac- tion at 0 to $2{ }^{\circ} \mathrm{C}$ in $90 \%$ acetone, pigments were measured fluorometrically (Turner Model 111) before and after acidification (Parsons et al. 1984). Concentrations of chlorophyll and phaeopigments were determined using the equations of Holm-Hansen et al. (1965); the calculation of phaeopigments was not corrected for molecular weight, and was therefore expressed in chlorophyll equivalents (cf. Conover et al. 1986). Counts of algal cells preserved in acid Lugol's were done under the inverted microscope (Lund et al. 1958).

\section{RESULTS}

\section{Algal biomass}

In 1986, the bloom of algae at the ice-water interface started in early April and ended in mid-May (Fig. 2). The interfacial algae reached peak concen-

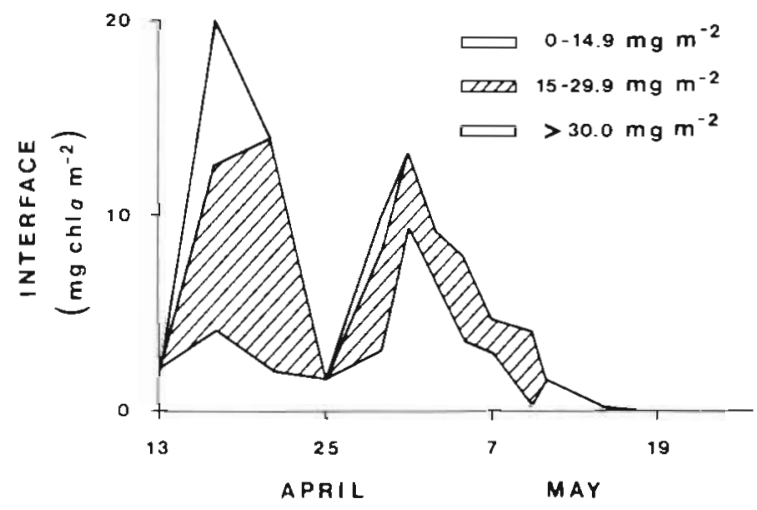

Fig. 2. Chlorophyll a concentrations $\left(\mathrm{mg} \mathrm{m}^{-2}\right.$ ) at ice-water interface showing estimated contribution of patches of high, medium, and low algal density

trations twice during the season, in the middle of April and at the beginning of May. The densest algal patch

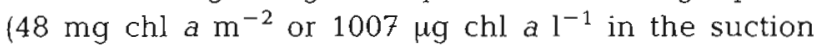
sample) and the highest mean algal density (20.0 $\mathrm{mg}$ chl $a \mathrm{~m}^{-2}$ ) were both observed on 17 April. Given ice algal growth rates at the sampling station (Gosselin pers. comm.), the rapid increase in chlorophyll concentration between 13 and 17 April cannot be explained by growth alone, and probably reflects partial sedimentation of algae from softening bottom ice into the interfacial layer. Chlorophyll levels at the interface sharply decreased between 21 and 25 April. This corresponded with a short atmospheric warming event that temporarily melted the snow cover, but it might also reflect perturbations of the sampling site by divers working in the same area for several days, as chlorophyll levels shifted back to high values after the diving site was moved by ca $150 \mathrm{~m}$ on 26 April. The decrease in 
concentrations of chlorophyll at the interface after the second peak in early May corresponded to the beginning of the spring melt period. This decline was well coupled with the increase in chlorophyll at $2.5 \mathrm{~m}$ (Fig. 3), suggesting that algae were gradually released from the under-ice layer into the water column. At the end of the season, depth-integrated concentrations of chlorophyll (linearly integrated from 0 to $30 \mathrm{~m}$ ) were roughly equivalent to areal concentrations measured at the interface in mid-April (Figs. 2 and 3).

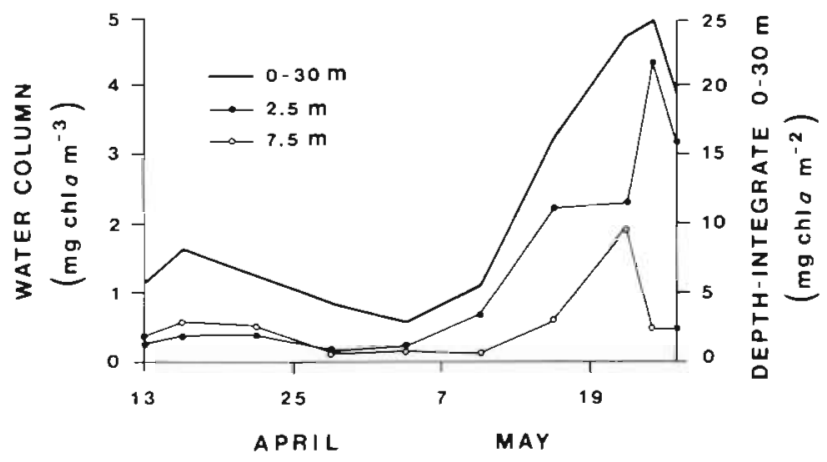

Fig. 3. Chlorophyll a concentrations in the water column at 2.5

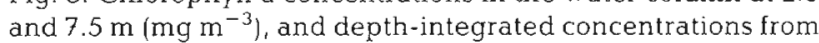
0 to $30 \mathrm{~m}\left(\mathrm{mg} \mathrm{m}^{-2}\right)$

All diatom species identified at $2.5 \mathrm{~m}$ were also observed at the ice-water interface during the ice algal bloom. However, there were striking differences in the relative abundances of species. In the water column, 64 to $95 \%$ of the total counts were microflagellates as compared with 8 to $13 \%$ at the interface (however, microflagellates accounted for only little biomass because of their small cellular volumes). Species composition at the interface, where Nitzschia spp. dominated throughout the season (Fig. 4A), was generally more stable than at $2.5 \mathrm{~m}$, where Navicula pelagica became relatively more abundant than Nitzschia spp. by early May (Fig. 4B). Steady increases in percent occurrences of $N$. pelagica and Chaetoceros spp. at $2.5 \mathrm{~m}$ in May suggest that these 2 diatoms were actively growing in the water column at this time (Fig. 4B).

\section{Potential grazers}

Nematodes were the most abundant animals in suction-gun samples ( 80 to $100 \%$ of total individuals), reaching peak concentrations of ca 200000 ind. $\mathrm{m}^{-2}$ during the first week of May. Harpacticoid copepods (Harpacticus superflexus, Ectinosoma sp.), the cyclopoid copepod Cyclopina schneideri, and calanoid copepods Pseudocalanus spp. were also common in suction samples (total mean concentrations ca 4000 ind. $\mathrm{m}^{-2}$ ). In the water column, copepods Pseudocalanus

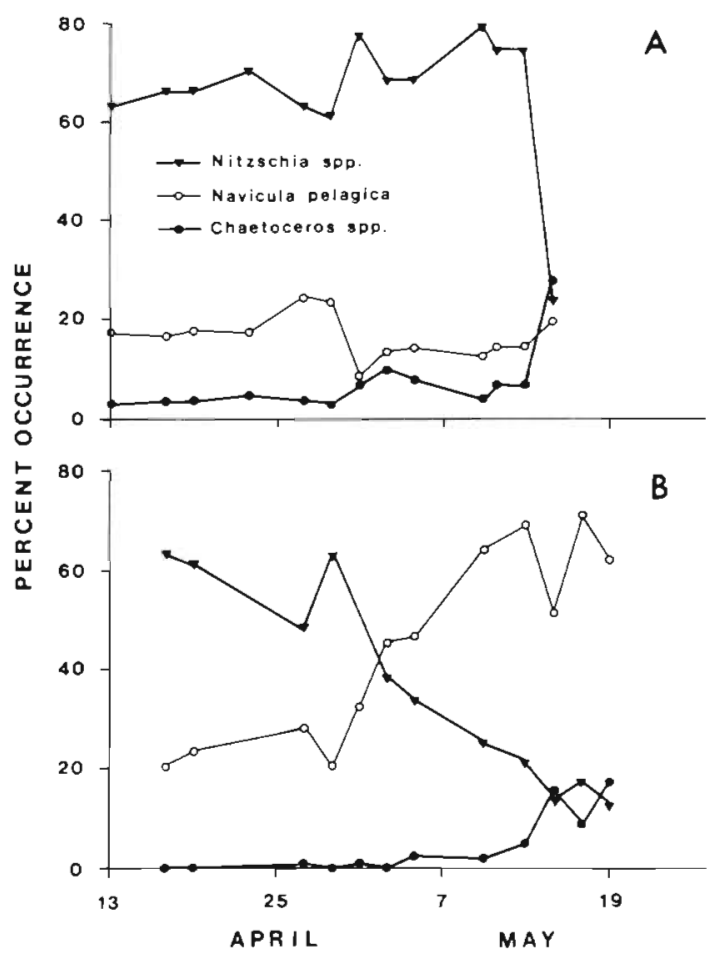

Fig. 4. Percent occurrence of dominant diatom taxa: (A) interfacial layer; (B) water column at $2.5 \mathrm{~m}$

spp. (ca 10000 adults and copepodites $\mathrm{m}^{-2}$ ) and Calanus glacialis (ca 100 adult females $\mathrm{m}^{-2}$ ) were always present. Larger herbivores like Calanus hyperboreus, euphausids and amphipods were present but uncommon.

\section{Feeding experiments}

Results of feeding experiments (Table 1) with Thalassiosira weissflogil show that $68 \%(\mathrm{CV}=13 \% ; \mathrm{n}=7)$ of pigments ingested were retrieved in the feces of planktonic herbivores Calanus glacialis and Pseudocalanus spp. We considered that pigments not recovered in feces were destroyed, since concentrations computed from the equations of Holm-Hansen et al. (1965) are already expressed in chlorophyll equivalents (Conover et al. 1986). For conversion of pigment fluxes into grazing rates (Tables 2 and 3), we assumed that the same loss $(32 \%)$ took place when copepods fed on ice algae we therefore divided the estimated amount of pigments in pellets by 0.68 .

\section{Pigment fluxes}

Except on a few occasions, coefficients of variation of pigment fluxes for the traps within the rosette were similar to those among the 5 traps, indicating that the 


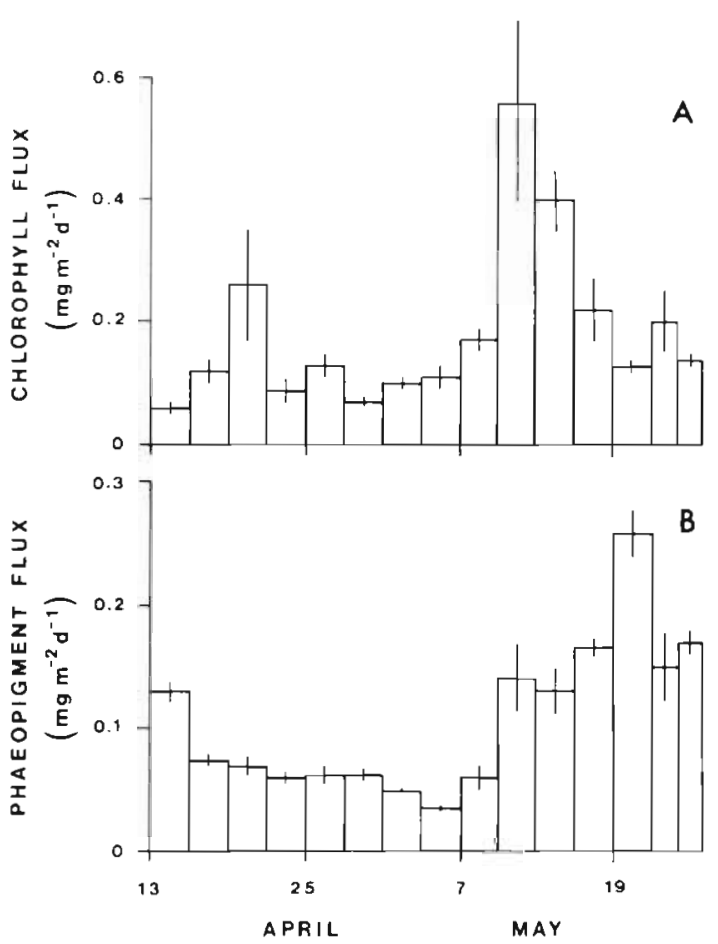

Fig. 5. Vertical pigment fluxes in chlorophyll equivalents (not corrected for molecular weight; see text). (A) Flux of chlorophyll $a ;(B)$ flux of phaeopigments. Means of 5 traps with associated standard errors

trapping method could not detect spatial variations at the scale of $50 \mathrm{~m}$ during the season. For this reason, chlorophyll and phaeopigment flux data from the 5 traps were pooled together irrespective of their spatial positions (Fig. 5). Fluxes (in chlorophyll equivalents) varied between 0.06 and $0.56 \mathrm{mg} \mathrm{m}^{-2} \mathrm{~d}^{-1}$ for chlorophyll, and between 0.035 and $0.26 \mathrm{mg} \mathrm{m}^{-2} \mathrm{~d}^{-1}$ for phaeopigments. Coefficients of variation ranged from 14 to $64 \%$ for chlorophyll and from 10 to $56 \%$ for phaeopigments. The largest flux of chlorophyll was measured from 10 to 13 May, at which time Nitzschia spp. represented $64 \%$ of sedimenting diatoms, Navicula pelagica $22 \%$, and Chaetoceros spp. $10 \%$. A minor peak was noted between 19 and 22 April; at this time, green flocs of aggregated cells were observed in the traps. Except at the very beginning of the season (13 to 16 April), phaeopigment fluxes stayed below $0.08 \mathrm{mg} \mathrm{m}^{-2} \mathrm{~d}^{-1}$ until $10 \mathrm{May}$. After this date, phaeopigment fluxes were 2 to 3 times higher, the maximum flux occurring between 19 and 22 May.

Pigment fluxes were converted into grazing and sinking losses, assuming that $32 \%$ chlorophyll equivalents were lost during digestion (Table 1) and that about $10 \%$ chlorophyll remained in fecal pellets (Lorenzen et al. 1983). This second factor was not considered by Welshmeyer \& Lorenzen (1985). Table 2 gives approximate values for losses via cell and pellet sedimentation as well as estimates for sedimentation rates of algae in the water column. Daily pellet sedimentation was always less than $2.3 \%$ of the total standing stock of chlorophyll a (interfacial + water column), while cell sedimentation was somewhat higher, up to $5.4 \%$ of the standing stock per day. Sedimentation rates of cells in the water column (calculated using depth-integrated chlorophyll concentrations) were generally $<1 \mathrm{~m} \mathrm{~d}^{-1}$ in April, then increased up to $2.1 \mathrm{~m} \mathrm{~d}^{-1}$ during the first $2 \mathrm{wk}$ of May, and decreased to $<0.4 \mathrm{~m} \mathrm{~d}^{-1}$ during the second half of May (Table 2). Using the same transformed fluxes, we estimated that total losses of chlorophyll crop were 14.7 $\mathrm{mg} \mathrm{m} \mathrm{m}^{-2}$ (95\% confidence intervals: 12.4 to $17.0 \mathrm{mg}$ $\mathrm{m}^{-2}$ ) during the $6 \mathrm{wk}$ covered by trap deployments (Table 3). Cell sinking and grazing by macrozooplankton explained equal proportions of this loss. Comparison of data for the first month (during the bloom) to those for the last 2 wk shows that daily losses of chlorophyll crop through pellet sinking were significantly more important after the bloom (Table 3).

Table 1. Results of chlorophyll degradation experiments with Hudson Bay copepods, Calanus glacialis and Pseudocalanus spp. (Pseu.), using cultures of Thalassiosira weissflogii. Recovery is calculated as $100 \cdot$ (fecal + gut)/(ingested)

\begin{tabular}{|c|c|c|c|c|c|c|c|}
\hline \multirow{2}{*}{$\begin{array}{l}\text { Feeding } \\
\text { animals }^{\mathrm{a}}\end{array}$} & \multirow{2}{*}{$\begin{array}{c}\text { Feeding } \\
\text { period } \\
\text { (h) }\end{array}$} & \multicolumn{5}{|c|}{ Total pigments (\% phaeo $)^{b}$} & \multirow{2}{*}{$\begin{array}{c}\text { Recovery } \\
(\%)\end{array}$} \\
\hline & & Initial & Final & $\begin{array}{l}\text { Ingested } \\
\text { (ug) }\end{array}$ & Fecal & Gut & \\
\hline 79 Calanus glacialis & 21.0 & 66.6 & 60.2 & 6.4 & $4.2(64)$ & 0.7 & 76.6 \\
\hline 13 ㅇ C g. & 25.5 & 66.6 & 45.8 & 20.8 & $13.8(80)$ & 1.3 & 72.6 \\
\hline 136 q. 213 cop Pseu. & 21.0 & 66.6 & 56.0 & 10.6 & $7.0(77)$ & 0.3 & 68.9 \\
\hline 112 9, 193 cop Pseu. & 25.5 & 66.6 & 55.1 & 11.5 & $6.0(80)$ & 0.3 & 54.8 \\
\hline $19 q C \cdot g$ & 10.0 & 18.8 & 10.2 & 8.6 & $4.9(90)$ & 1.9 & 79.1 \\
\hline 17 . C. $\mathrm{g}$ & 22.0 & 18.8 & $4.2(10)$ & 14.6 & $7.7(91)$ & 1.7 & 64.4 \\
\hline 14 으. $g$. & 30.0 & 18.8 & $1.5(58)$ & 17.3 & $8.7(90)$ & 1.4 & 58.4 \\
\hline
\end{tabular}


Table 2. Total (TCS) and suspended (CS $\mathrm{CS}_{0-30}$ ) average chlorophyll standing stocks during deployments; daily losses (percent) of TCS of algal pigments by grazing and cell sinking; and cell sedimentation rates. Losses calculated assuming that $32 \%$ of pigments ingested by herbivores were lost during digestion and that the ratio of chlorophyll to total pigment in fecal pellets was $10 \%$

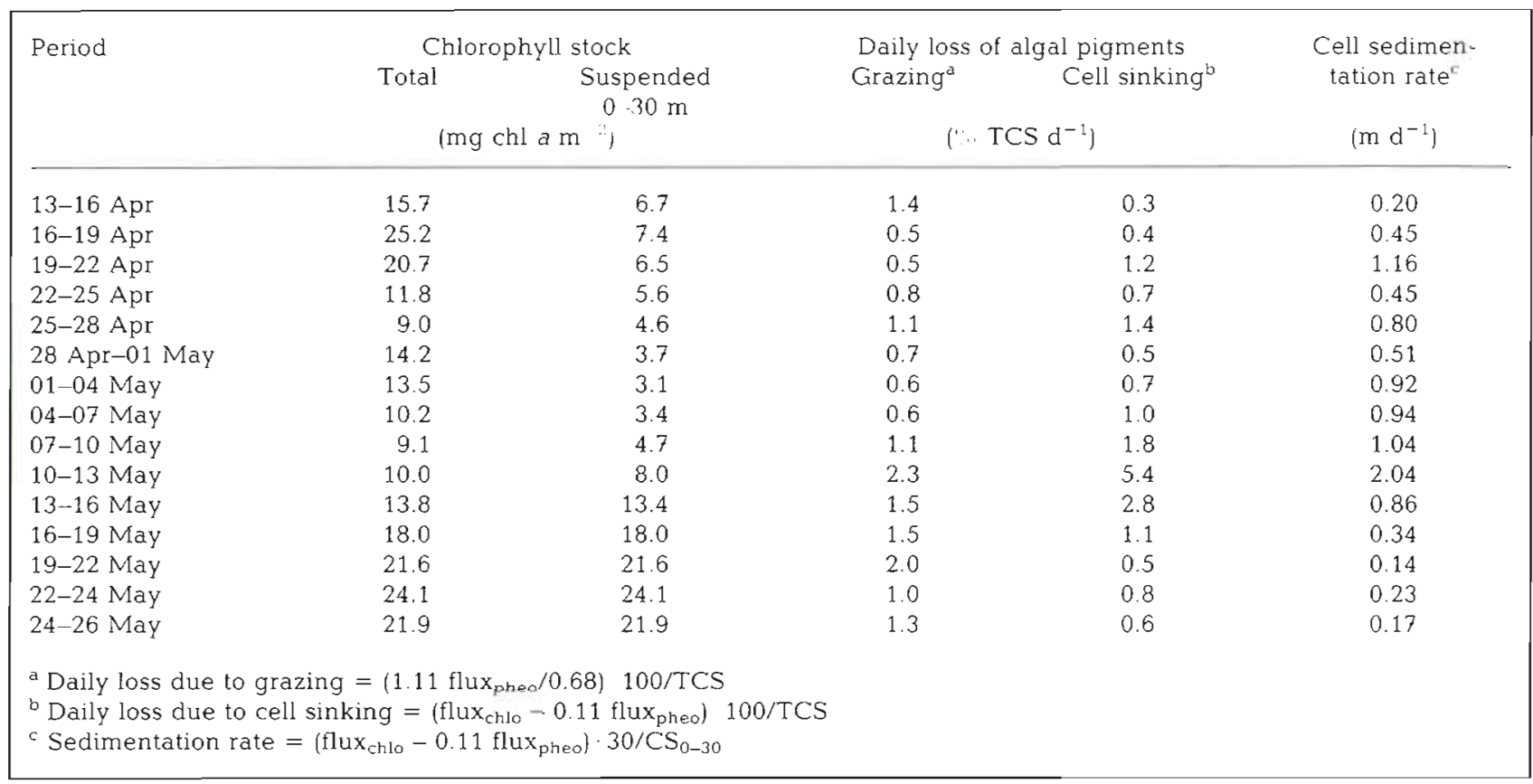

Table 3. Losses of chlorophyll (total biomass and daily rate) to the bottom (cell sinking) and to grazers, as estimated from sediment trap data. Means and $95 \%$ confidence intervals $(n=5)$ for the entire sampling period (13 Apr-26 May), and for 'bloom period' (13 Apr-13 May) and 'post-bloom' period (13 May-26 May) separately. For each period, variance is calculated as the sum of variances measured during each deployment

\begin{tabular}{|c|c|c|c|c|c|}
\hline \multirow[t]{2}{*}{ Period } & & \multicolumn{2}{|c|}{$\begin{array}{l}\text { Estimated losses of chlorophyll biomass } \\
\left.\text { (mg chl } \mathrm{a} \mathrm{m}^{-2}\right)\end{array}$} & \multicolumn{2}{|c|}{$\begin{array}{l}\text { Daily rates of loss } \\
\left(\mathrm{mg} \mathrm{chl} \mathrm{a} \mathrm{m}^{-2} \mathrm{~d}^{-1}\right)\end{array}$} \\
\hline & & Sinking & Grazing & Sinking & Grazing \\
\hline 13 Apr-26 May & $\begin{array}{c}\bar{x} \\
95 \% \mathrm{CI}\end{array}$ & $\begin{array}{c}7.46 \\
(5.94-8.98)\end{array}$ & $\begin{array}{c}7.24 \\
(6.48-7.99)\end{array}$ & $\begin{array}{c}0.173 \\
(0.138-0.208)\end{array}$ & $\begin{array}{c}0.168 \\
(0.151-0.185)\end{array}$ \\
\hline $\begin{array}{l}13 \mathrm{Apr}-13 \mathrm{May} \\
\text { bloom period' }\end{array}$ & $\begin{array}{c}\bar{x} \\
95 \% \mathrm{CI}\end{array}$ & $\begin{array}{c}4.78 \\
(3.38-6.17)\end{array}$ & $\begin{array}{c}3.61 \\
(3.05-4.17)\end{array}$ & $\begin{array}{c}0.159 \\
(0.113-0.206)\end{array}$ & $\begin{array}{c}0.120 \\
(0.101-0.139)\end{array}$ \\
\hline $\begin{array}{l}13 \text { May-26 May } \\
\text { post-bloom }\end{array}$ & $\begin{array}{c}\bar{x} \\
95 \% \mathrm{CI}\end{array}$ & $\begin{array}{c}2.68 \\
(2.06-3.29)\end{array}$ & $\begin{array}{c}3.62 \\
(3.10-4.14]\end{array}$ & $\begin{array}{c}0.208 \\
(0.158-0.253)\end{array}$ & $\begin{array}{c}0.278 \\
(0.238-0.318)\end{array}$ \\
\hline
\end{tabular}

\section{Fecal pellet identification}

Ellipsoidal pellets and 3 size classes of cylindrical pellets (mean dimensions in Table 4) were observed in the traps. The 2 smaller size classes (ellipsoidal and small cylindrical pellets) were also found in some suction-gun samples. Recognizable frustules of ice diatoms (species of Nitzschia and Navicula) were observed in all 4 types of fecal pellets. Small and medium cylindrical pellets had dimensions similar to those produced by members of the genera Pseudocalanus and Calanus during the feeding experiments
Table 4. Mean dimensions of fecal pellets caught in sedment traps

\begin{tabular}{|c|c|c|c|c|}
\hline \multirow[t]{3}{*}{ Shape } & \multicolumn{4}{|c|}{ Mean dimensions (um) } \\
\hline & \multicolumn{2}{|c|}{ Length } & \multicolumn{2}{|c|}{ Width } \\
\hline & $\overline{\mathrm{x}}$ & $\mathrm{SD}$ & $\overline{\mathrm{x}}$ & SD \\
\hline \multicolumn{5}{|l|}{ Cylindrical } \\
\hline Small $(\mathrm{n}=20)$ & 203 & 38 & 20.4 & 4.2 \\
\hline Medium $(n=30)$ & 784 & 98 & 82 & 8 \\
\hline Large $(n=15)$ & 1338 & 294 & 128 & 27 \\
\hline Ellipsoidal & ca 150 & & ca 60 & \\
\hline
\end{tabular}




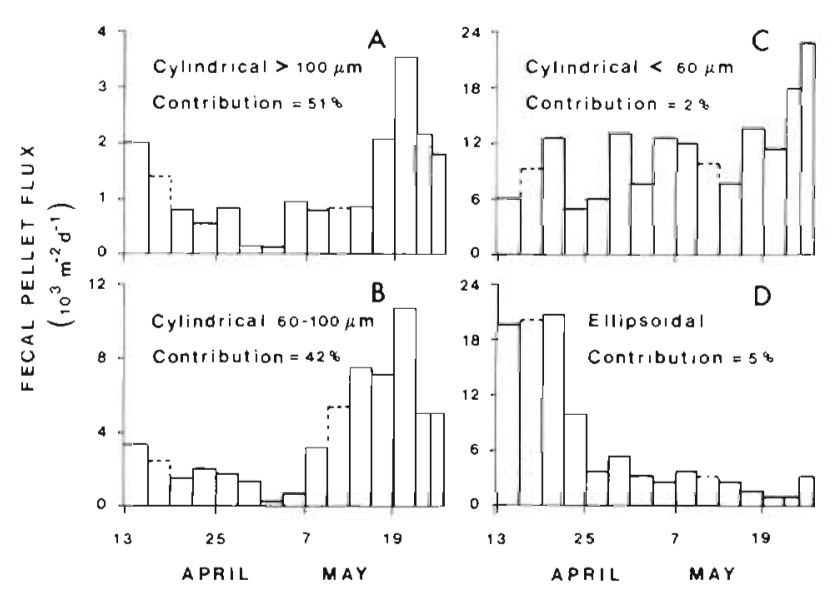

Fig. 6. Fecal pellet fluxes and contribution (by volume) to the total catch of pellets during the season. (A) Large cylindrical pellets, diam. $100 \mu \mathrm{m}_{\text {; }}$ (B) medium cylindrical pellets, diam. 60 to $100 \mu \mathrm{m}$; (C) small cylindrical pellets, diam. $<60 \mu \mathrm{m}$; (D) ellipsoidal pellets. Dotted lines: missing values for which fluxes were linearly interpolated

Ellipsoidal and largest size classes of cylindrical fecal pellets were not seen during the feeding experiments. Fig. 6 gives the fluxes for these 4 categories of fecal pellets as well as the contributions of each type to total trap recovery (by volume). Assuming that small and medium cylindrical pellets were only produced by Pseudocalanus spp. and Calanus spp., fluxes measured varied between 0.5 and 2.3 pellets ind.$^{-1} \mathrm{~d}^{-1}$ for small pellets, and between 1 and 76 pellets ind. ${ }^{-1} \mathrm{~d}^{-1}$ for medium-sized pellets (Fig. 6B, C). Regression of pellet flux versus phaeopigment flux (Fig. 7) confirms that phaeopigments collected in the traps came principally from fecal pellets; the total volumal flux of pellets was strongly related to phaeopigment flux and the intercept was not significantly different from zero.

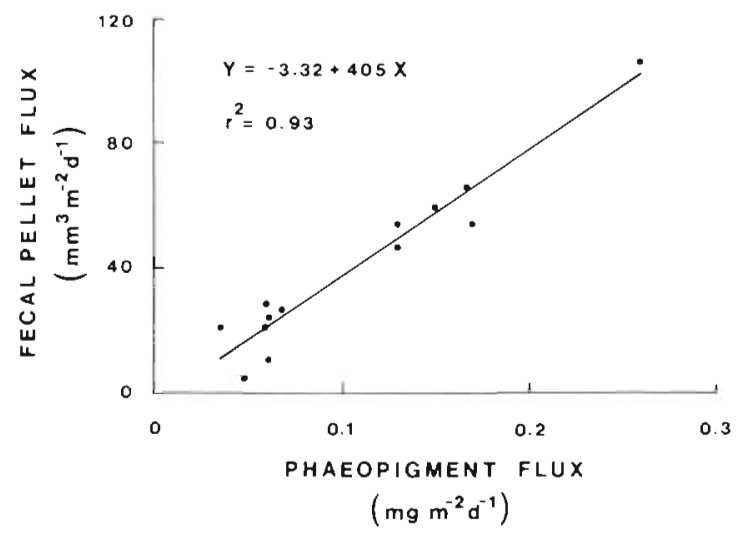

Fig. 7. Regression of fecal pellet flux (by volume) on phaeopigment flux

\section{DISCUSSION}

During the sampling season, short and consecutive deployments of sediment traps made it possible to monitor the sinking of pigmented particulate matter on a relatively fine temporal scale. Moreover, particulate flux was measured up to $10 \mathrm{~d}$ after the end of the bloom, which has not previously been done in environments where ice algal blooms end at the same time as ice break-up (Dumbar et al. 1985a, Carey 1987). There were 2 peaks of sinking cells during the season, a minor one during the third week of April and a major one at the end of the ice algal bloom, in mid-May. Both the flux of phaeopigments and the flux of fecal pellets suggest that the grazing impact of large herbivores increased after the end of the ice algal bloom. We shall first discuss these features, and conclude with an analysis of the fate of ice algal production, particularly with respect to the relative importance of export toward the benthos versus water column processes.

\section{Sedimentation of algal cells}

The 2 sinking events recorded in the traps (Fig. 5A) occurred a few days following the 2 decreases in biomass observed at the interface (Fig. 2), suggesting that cell sedimentation primarily reflected pulsed releases of algae from the interfacial layer. Melting events may have contributed in 2 ways to release of algal cells. First, the amount of heat absorbed by ice algae probably increased as the snow cover melted, thus accelerating the melt of the under-ice layer (Apollonio 1965, Meguro et al. 1967). Secondly, melt water at the ice surface could easily percolate through the ice and flush algal cells. Under-ice currents may also play a role in sporadic loss of ice algae at the interface (McGrath-Grossi et al. 1987) but we did not find evidence for this in the present study.

Cell aggregation probably also influences the timing and magnitude of sedimentation of ice algae. The presence of algal aggregates in the 19 to 22 April traps is consistent with the short time lag (less than $5 \mathrm{~d}$ ) between the first decline in biomass at the interface (Fig. 2) and the first sedimentation event (Fig. 5A). These aggregates might have come from the very dense patches of ice algae observed on 17 April (>30 $\mathrm{mg} \mathrm{chl} \mathrm{a} \mathrm{m} \mathrm{m}^{-2}$; Fig. 2). This hypothesis is supported by observations that suction-gun samples from these patches had a tendency to form large aggregates. Contrary to Sasaki \& Hoshiai (1986), who saw large algal aggregates in their traps during most of the ice algal bloom, we observed this event only once in Hudson Bay in 1986.

Unhealthy algal cells usually sink faster than healthy 
and actively growing ones (Smayda 1970, Walsby \& Reynolds 1980). Sedimentation rates of algae in the water column, calculated from trap data and depthintegrated chlorophyll levels, increased steadily during the first 2 wk of May (Table 2). Bioassays performed at the same location did show that ice algae started to be silicon-deficient at the beginning of May (Gosselin unpubl.), which has been shown to increase the sinking rates of some diatoms (Bienfang et al. 1982, Bienfang \& Harrison 1984, Harrison et al. 1986). Later in May, input of fresh meltwater may also have had adverse effects on cells suspended in the water column. In addition to increasing mean sedimentation rate of water column algae, silicon deficiency and meltwater input may have played a role in differential sedimentation of Nitzschia spp., which progressively disappeared from the surface layer in May and became dominant a few days later in the traps (10 to 13 May). During the second half of May, calculated sedimentation rates decreased to values lower than earlier in the season (Table 2). This could indicate that the new assemblage of species that took over (Navicula pelagica, Chaetoceros spp., microflagellates) were better adapted to pelagic life and actively photosynthesizing at that time.

\section{Grazing by meio- and macrofauna}

Grazers that contributed the most to the observed vertical pellet flux were macrozooplankton, including Calanus glacialis (medium-sized, cylindrical pellets) and unidentified large herbivores (large-sized pellets), possibly amphipods, euphausids, and the large copepod Calanus hyperboreus, that were occasionally found in net samples. The contribution of small cylindrical and ellipsoidal pellets, presumably originating from respectively small planktonic calanoid copepods (predominantly Pseudocalanus spp.) and sympagic harpacticoid copepods, was small. However, Pseudocalanus and harpacticoid copepods were actively feeding during the ice algal bloom (Runge \& Ingram 1988, own obs.), and we cannot rule out the possibility that trap observations do not accurately represent the relative contribution of these small animals to total grazing pressure, as small pellets are likely to be broken up, eaten, or degraded in the water column (Paffenhöfer \& Knowles 1978, Hofmann et al. 1981).

Grazing pressure from the macrofauna, as estimated by phaeopigment fluxes, was moderate and relatively stable during the ice algal bloom but increased with the release of ice algae into the water column. This result is similar to Antarctic observations of Sasaki \& Hoshiai (1986), who also found an increased grazing impact after the ice algal bloom. They proposed that pelagic herbivores could not efficiently capture large, fast sink- ing aggregates that were more abundant during the bloom period. As aggregates were not very abundant in our trap samples during the bloom, higher grazing activity after the decline of the bloom was more likely the result of a greater accessibility of ice algae to suspension-feeding planktonic herbivores. For example, Calanus glacialis, which is known to feed on ice microalgae very near the interface during the ice algal bloom (Runge \& Ingram 1988), appeared to be feeding at higher rates after the bloom when the algae were more dispersed in the water column (Runge unpubl.).

In a study of particle flux beneath the fast ice of southeastern Beaufort Sea, Carey (1987) observed higher fecal pellet fluxes at the peak of the ice algal bloom, rather than later as we observed in Hudson Bay. This difference may depend on the composition of the grazing community. On the shallow Alaskan shelf (station depth: $8 \mathrm{~m}$ ), the predominant grazer was the

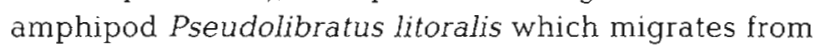
the bottom to the undersurface of the ice in early spring. At our station in Hudson Bay, deep shoreward water in excess of $100 \mathrm{~m}$ may have limited colonization by benthic amphipods and favored grazing dominance by pelagic zooplankton that fed at higher rates on ice algae released after the interfacial bloom.

\section{Pelagic retention of ice algal production}

Exports to the benthos estimated from pigments in the traps generally represented a very small portion of the total chlorophyll standing crop. Assuming that the efficiency of the traps was close to $100 \%$, the proportion of the algal stock lost daily to sinking cells and pellets was generally $<2 \%$, with a peak of $8 \%$ when the ice started to melt in mid-May (Table 2). Our data indicate that a large proportion of the bottom-ice production remained suspended in the water column throughout the sampling period. Even $10 \mathrm{~d}$ after the end of the ice algal bloom, there were still ca $20 \mathrm{mg}$ chl $a^{-2}$ in the water column (Fig. 3), compared to only 12 to $17 \mathrm{mg} \mathrm{chl} \mathrm{a} \mathrm{m} \mathrm{m}^{-2}$ possibly lost to the benthos through grazing and cell sedimentation (Table 3). Using $\mathrm{C}^{14}$, ice-associated production for the whole season was estimated to be $3.2 \mathrm{~g} \mathrm{C} \mathrm{m}^{-2}$ or ca $70 \mathrm{mg} \mathrm{chl} \mathrm{a} \mathrm{m}^{-2}$ (Gosselin pers. comm.). A quick budget calculated from these numbers indicates that ca $20 \%$ ( 17 to $24 \%$ ) of the chlorophyll a produced during the season sank to the benthos (half through macrozooplankton grazing and half through cell sinking; Table 3 ), ca $30 \%$ were still suspended in the water column at the end of the sampling season, while ca $50 \%$ were unaccounted for.

We are not able to quantify the errors associated with our estimates of algal biomass at the interface and in the water column; an overestimate of the former or an 
underestimate of the latter might account for the ca $50 \%$ of chlorophyll equivalents that our budget does not account for. In addition, rapid loss of pigment fluorescence due to cell plasmolysis and bacterial degradation of senescent algae (Horner \& Schrader 1982), pigment bleaching (Apollonio 1965), grazing by small herbivores (SooHoo and Kiefer 1982, Welshmeyer \& Lorenzen 1985), and the break-up of large fecal pellets during sinking (Laws et al. 1988) could not be quantified by our approach. Some of these processes probably operated during the spring of 1986, transforming ice algal production in the water column into non-fluorescent forms and thus accounting for part of the imbalance in the pigment budget. Finally, we did not consider the possibility of horizontal advection which, combined with a horizontal gradient in underice production, could have resulted in an underestimate in the quantity of material sedimenting at our sampling site.

Two important conclusions of this study are: (1) The residence time of ice algae in the water column was long, since relatively few ice algae sank to depth during and after the interfacial bloom (6 to $9 \mathrm{mg}$ chl $a$ or ca $10 \%$ of the production, which is small when compared to massive sinking of some spring phytoplankton blooms (e.g. Schnack et al. 1985, Smetacek 1985). (2) Dominant herbivores in Hudson Bay appeared to be actively feeding on algae suspended in the water column; this suggests that most of the ice algal production was channeled into the pelagic ecosystem during the spring 1986 in Hudson Bay.

Acknowledgements. This research was funded by individual operating grants to J.A.R. and L. I. from the Natural Sciences and Engineering Research Council of Canada (NSERC), by the Department of Fisheries and Oceans, and by grants to GIROQ from NSERC, the Canadian Donner Foundation, and the Fonds FCAR of Québec. C.T received a postgraduate scholarship from NSERC, and financial support from the Department of Indian and Northern Affairs for field work. We gratefully acknowledge the invaluable assistance of C. Côté at the Centre d'études nordiques, Université Laval, in Kuujjuarapik. Sediment traps were kindly provided by B. d'Anglejan. We thank P. Jalbert, M. Dubé, P. Joly and SCUBA divers for assistance in the field. P. Jalbert enumerated algal cells, and E. H. Grainger and A. Mohammed assisted in identification of meiofauna. The manuscript benefited from comments by $M$. Gosselin.

\section{LITERATURE CITED}

Alexander, V. (1980). Interrelationships between the seasonal sea ice and biological regimes. Cold Regions Sci. Tech. 2: $157-178$

Alexander, V., Homer, R. A., Clasby, R. C. (1974). Metabolism of Arctic sea-ice organisms. Rep. Inst. Mar. Sci. Univ. Alaska R 74-4

Apollonio, S. (1965). Chlorophyll in Arctic sea ice. Arctic 18: $118-122$
Atkinson, E. G., Wacasey, J. W (1987). Sedimentation in Arctic Canada: particulate organic flux to a shallow marine benthic community in Frobisher Bay. Polar Biol. 8: 3-7

Bienfang, P. K., Harrison, P. J. (1984). Sinking-rate response of natural assemblages of temperate and subtropical phytoplankton to nutrient depletion. Mar. Biol. 83: 293-300

Bienfang, P. K., Harrison, P. J., Quarmby, L. M. (1982). Sinking rate response to depletion of nitrate, phosphate and silicate in four marine diatoms. Mar. Biol. 67: 295-302

Booth, J. A. (1984). The epontic algal community of the ice edge zone and its significance to the Davis Strait ecosystem. Arctic 37: 234-243

Bradstreet, M. S. W., Cross, W. E. (1982). Trophic relationships at high Arctic ice edges. Arctic 35: 1-12

Carey, A. G. (1985). Marine ice fauna: Arctic. In: Horner, R. A. (ed.) Sea ice biota. CRC Press, Boca Raton, p. 173-190

Carey, A. G. (1987). Particle flux beneath fast ice in the shallow southwestern Beaufort Sea, Arctic Ocean. Mar. Ecol. Prog. Ser. 40: 247-257

Conover, R. J., Durrvasula, R., Roy, S., Wang, R. (1986). Probable loss of chlorophyll-derived pigments during passage through the gut of zooplankton, and some of the consequences. Limnol. Oceanogr. 31: 878-887

Cross, W. E. (1982). Under-ice biota at the Pond Inlet ice edge and in adjacent fast ice areas during spring. Arctic 35: $13-27$

Dagg, M. J., Edward Walser Jr, W. (1987). Ingestion, gut passage, and egestion by the copepod Neocalanus plumchrus in the laboratory and in the Subarctic Pacific Ocean. Limnol. Oceanogr 32: 178-188

d'Anglejan, B., Biksham, G. (1988). Late winter - early spring sedimentation of the Great Whale River, southeastern Hudson Bay. Can. J. Earth Sci. 25: 930-933

Demers, S., Legendre, L., Therriault, J.-C., Ingram, R. G. (1986). Biological production at the ice-water ergocline. In: Nihoul, J. C. J. (ed.) Marine interfaces ecohydrodynamics. Elsevier, Amsterdam, p. 31-54

Dunbar, R. B., Leventer, A. R., Marty, R. C. (1985a). Vertical sediment flux beneath annual sea ice, McMurdo Sound, Antarctica. Antarctic J. U.S. 20: 109-111

Dunbar, R. B., Macpherson, A. J., Wefer, G. (1985b). Water column particulate flux and seafloor deposits in the Bransfield Strait and Southern Ross Sea, Antarctica. Antarctic J. U.S. 20: $98-100$

Fukuchi, M., Sasaki, H. (1981). Phytoplankton and zooplankton standing stocks and downward flux of particulate material around fast ice edge of Lützow-Holm Bay, Antarctica. Mem. Natl Inst. Polar Res. (Ser. E) 34: 13-36

Gosselin, M., Legendre, L., Therriault, J. C., Demers, S., Rochet, M. (1986). Physical control of the horizontal patchiness of sea-ice microalgae. Mar. Ecol. Prog. Ser. 29: 289-298

Green, K. A. (1976). Simulation of the pelagic ecosystem of the Ross Sea, Antarctica: a time varying compartmental model. Univ. Microfilms International, Ann Arbor, USA

Hargrave, B. T., Phillips, G. A., Taguchi, S. (1976). Sedimentation measurements in Bedford Basin, 1973-74. Fish. Mar. Serv. Res. Dev. Tech. Rep. 608: 1-129

Harrison, P. J., Turpin, D. H., Bienfang, P. K., Davis, C. O. (1986). Sinking as a factor affecting phytoplankton species succession: the use of selective loss semi-continuous cultures. J. exp. mar. Biol. Ecol. 99: 19-30

Helling, G. R., Baars, M. A. (1985). Changes of the concentration of chlorophyll and phaeopigment in grazing experiments. Hydrobiol. Bull, 19: 41-48

Hofmann, E. E., Klinck, J. M., Paffenhöfer, G.-A. (1981). Concentrations and vertical fluxes of zooplankton fecal pellets on a continental shelf. Mar. Biol 61: 327-335 
Holm-Hansen, O., Lorenzen, C. J., Holmes, R. W., Strickland, J. D. H. (1965). Fluorometric determination of chlorophyll J. Cons. perm. int. Explor Mer 30: 3-15

Horner, R. (1984). Do ice algae produce the spring phytoplankton bloom in seasonally ice-covered waters? $A$ review of recent literature. In: Mann, D. G. (ed.) Proc. 7th Int. Diatom Symp. Otto Koeltz, Königstein, p. 401-409

Horner, R. A. (1985). History of ice algal investigations. In Horner, R. A. (ed.) Sea ice biota. CRC Press, Boca Raton, p. $1-20$

Homer, R., Schrader, G. C. (1982). Relative contributions of ice algae, phytoplankton and benthic microalgae to primary production in nearshore regions of the Beaufort Sea. Arctic 35: 485-503

Hsiao, S. I. C. (1987). Sedimentation in Arctic Canada: species composition and biomass of phytoplankton contributed to the marine sediments in Frobisher Bay. Polar Biol. 7: $245-251$

Kiørboe, T., Tiselius, P. T. (1987). Gut clearance and pigment destruction in a herbivorous copepod, Acartia tonsa, and the determination of in situ grazing rates. J. Plankton Res 9: $525-534$

Laws, E. A., Bienfang, P. K., Ziemann, D. A., Conquest, L. D (1988). Phytoplankton population dynamics and the fate of production during the spring bloom in Auke Bay, Alaska. Limnol. Oceanogr 33: 57-65

Legendre, L., Ingram, R. G., Poulin, M. (1981). Physical control of phytoplankton production under sea ice (Manitounuk Sound, Hudson Bay). Can. J. Fish. Aquat. Sci. 38 $1385-1392$

Lorenzen, C. J., Welshmeyer, N. A., Copping, A. E, Vernet, M. (1983). Sinking rates of organic particles. Limnol Oceanogr. 28: 766-769

Lund, J. W. G., Kipling, C., Le Cren, E. D. (1958). The inverted microscope method of estimating algal numbers and the statistical basis of estimations by counting. Hydrobiologica 11: $143-170$

McGrath-Grossi, S., Kottmeir, S. T., Moe, R. L., Taylor, G. T. Sullivan, C. W. (1987). Sea ice microbial communities. VI. Growth and primary production in bottom ice under graded snow cover. Mar Ecol. Prog. Ser 35: 153-164

Meguro, H., Ito, K., Fukushima, H. (1967). Ice flora (bottom type): a mechanism of primary production in polar seas and the growth of diatoms in sea ice. Arctic 20:114-133

Niebauer, H. J., Alexander, V., Cooney, R. T. (1981). Primary production at the eastern Bering Sea ice edge: the physical and biological regimes. In: Hood, D. W., Calder, J. A. (eds.) The eastern Bering Sea shelf: oceanography and resources, Vol. 2. Univ. Washington Press, Seattle, p. 763-772

This article was submitted to the editor
Paffenhöfer, G.-A., Knowles, S. C. (1978). Ecological implications of fecal pellet size, production and consumption by copepods. J. mar. Res. 37: 35-49

Parsons, T R., Maita, Y., Lalli, C. M. (1984). A manual of chemical and biological methods for seawater analysis. Pergamon Press, New York

Roff, J. C., Legendre, L. (1986). Physico-chemical and biological oceanography of Hudson Bay. In: Martini, I. P. (ed.) Canadian inland seas. Elsevier, Amsterdam, p. 265-291

Runge, J. A., Ingram, R. G. (1988). Underice grazing by planktonic, calanoid copepods in relation to a bloom of ice microalgae in southeastern Hudson Bay. Limnol Oceanogr. 33: 282-288

Sasaki, H., Hoshiai, T. (1986). Sedimentation of microalgae under the Antarctic fast ice in summer. Mem. natn. Inst polar Res. (Spec. Issue) 40: 45-55

Schnack, S. B., Smetacek, V., Bodungen, B. von, Stegmann, P. (1985). Utilisation of phytoplankton by copepods in Antarctic waters during spring. In: Gray, J., Christensen, M. E. (eds.) Marine biology of polar regions and effects of stress on marine organisms. John Wiley, New York, p. $65-81$

Shuman, F. R., Lorenzen, C. J. (1975). Quantitative degradation of chlorophyll by a marine herbivore. Limnol. Oceanogr 20: 580-586

Smayda, T. (1970). The suspension and sinking of phytoplankton in the sea. Oceanogr. mar Biol. A. Rev. 8: 353-414

Smetacek, $V$ (1985). Role of sinking in diatom live-history cycles: ecological, evolutionary and geological significance. Mar. Biol. 84: 239-251

Smetacek, V., Brockel, K. von, Zeitzschel, B., Zenk, W. (1978). Sedimentation of particulate matter during a phytoplankton bloom in relation to the hydrographical regine. Mar. Biol. 47. 211-226

SooHoo, J. B., Kiefer, D. A. (1982). Vertical distribution of phaeopigments. I: A simple grazing and photooxidative scheme for small particles. Deep Sea Res. 29: 1539-1552

Subba Rao, D. V., Platt, T (1984). Primary production of Arctic waters. Polar Biol. 3: 191-201

Walsby, A. E., Reynolds, C. S. (1980). Sinking and floating. In: Morris, I. (ed.) The physiological ecology of phytoplankton. Univ. Calif. Press, Berkeley, p. 371-412

Wang, R., Conover, R. J. (1986). Dynamics of gut pigments in the copepod Temora longicornis and the determination of in situ grazing rates. Limnol. Oceanogr. 31: 867-877

Welshmeyer, N. A., Lorenzen, C. J. (1985). Chlorophyll budgets: zooplankton grazing and phytoplankton growth in a temperate fjord and the Central Pacific Gyres. Limnol. Oceanogr. 30: $1-21$

Manuscript first received: July 15, 1988

Revised version accepted: May 19, 1989 